\title{
PEMENUHAN KEBUTUHAN AKAN KELEKATAN PADA ANAK DALAM KONTEKS BUDAYA BENGKULU
}

\author{
Dian Mustika Maya, Zumkasri \\ Fakultas Keguruan dan Ilmu Pendidikan Universitas Prof.Dr.Hazairin.,SH Bengkulu \\ Jl. Achmad Yani No.1 Kota Bengkulu \\ mustikamaya@gmail.com
}

\begin{abstract}
This qualitative study aims to explore how mothers fulfill the need for attachment on their children in the context of Bengkulu culture. The study participants comprised five mothers that were identified using purposive sampling method. The following characteristics were applied: 1) the third generation of a family that lived in Bengkulu, 2) the nuclear family lives together, 3) she has a child with a minimum of 2 years of age, and 4) she uses local language to communicate within the family. The data analysis resulted in the following 10 themes or categories: 1) The use of local language to respond to the child's need for attachment; 2) The attached figure (mother) used an insecure attachment; 3) Mother responds spontaneously depends on the situation; 4) The tone of mother's voice affects the child's perception; 5) The mother's emotion influences her chosen words; 6) The intrinsic factors that affect the fulfillment of child's attachment were marriage readiness, the quality of marriage relationship, and verbal ability; 7) The extrinsic factors affect the fulfillment of child's need for attachment were financial condition, the environment where the participants lived, and education level; 8) Treating a child as an object; 9) The structure of extended family reinforces child's insecure attachment; 10) Interaction pattern and character of the society.
\end{abstract}

Keywords: child; language; parenting; need attachment; culture

\begin{abstract}
Abstrak
Penelitian kualitatif ini bertujuan untuk mengetahui bagaimana figure lekat (ibu) melakukan pemenuhan kebutuhan kelekatan pada anak, ditinjau dari konteks budaya Bengkulu. Subjek penelitian terdiri dari lima orang yang ditentukan secara purposive dengan karakteristik: 1) keluarga turunan ketiga yang menetap di Bengkulu, 2) keluarga inti tinggal dalam satu rumah, 3) memiliki anak minimal berusia dua tahun, dan 4) interaksi antar keluarga menggunakan bahasa daerah. Hasil analisis data mendapatkan 10 kategorisasi atau unit makna, yaitu: 1) Penggunaan bahasa Bengkulu oleh figur lekat dalam merespon kebutuhan kelekatan anak; 2) Figur lekat menerapkan insecure attachment; 3) Reaksi spontan berdasar situasi merupakan bentuk respon figur lekat terhadap anak; 4) Intonasi suara dari figur lekat mempengaruhi persepsi anak; 5) Emosi mempengaruhi pemilihan kata pada figur lekat; 6) Faktor internal pemenuhan kelekatan anak, antara lain: kesiapan pernikahan, kualitas hubungan pernikahan, dan kemampuan berbahasa; 7) Faktor eksternal pemenuhan kelekatan adalah kondisi ekonomi, lingkungan dimana subjek tinggal, serta tingkat pendidikan; 8) Anak sebagai objek pelampiasan; 9) Struktur keluarga besar (extended family) menguatkan insecure attachment pada anak; 10) Pola interaksi dan karakter masyarakat.
\end{abstract}

Kata kunci: anak; bahasa; pola asuh; kelekatan; budaya; Bengkulu

\section{PENDAHULUAN}

Kebutuhan kelekatan merupakan salah satu kebutuhan dasar manusia yang akan mempengaruhi optimalisasi tahapan perkembangan manusia pada periode- periode berikutnya. Pada kelekatan, anak mencari dan mempertahankan kontak dengan orang-orang tertentu saja. Kelekatan muncul karena anak merasa dipenuhi kebutuhannya baik secara fisik maupun psikologis. Pengaruh kebutuhan 
kelekatan tidak berhenti pada masa kanak-kanak, lebih lanjut kebutuhan kelekatan juga akan mempengaruhi gaya interaksi seseorang dalam menjalin hubungan pribadi atau intimasi pada masa dewasa. Menurut Erikson, proses intimasi diawali oleh penetapan yang jelas mengenai identitas dirinya. Jika intimasi tidak berkembang, maka akan terjadi isolasi (Santrock, 1999).

Pada masa anak, proses perkembangan kognitif masih berada pada tahap operasional kongkret, artinya anak hanya mengartika apa yang dilihat, didengar, dan dirasakannya saja. Sehingga jika figur lekat dalam berinteraksi dengan anak tidak memperhatikan kondisi anak, berbicara dengan pemilihan kata yang kasar, dengan nada ancaman, dan intonasi keras maka anak akan mengartikan sebagai mana yang dirasakan. Hal ini yang memicu membentuk pola kelekatan tidak aman (insecure attachment) (Bretherton, 1992).

Berdasarkan hasil penelitian dengan berbagai perspektif, telah terbukti bahwa pemenuhan kebutuhan kelekatan pada anak berdampak pada banyak aspek saat memasuki masa dewasa. Pada konteks budaya Humboldt (dalam Chaer, 2003) menekankan adanya ketergantungan pemikiran manusia pada bahasa. Kedua bentuk bahasa yaitu bunyi dan pikiran membelenggu manusia, dan menentukan jalan pikirannya. Artinya, pandangan hidup dan budaya suatu masyarakat ditentukan oleh bahasa masyarakat itu sendiri, dan anggota masyarakat tidak dapat menyimpang dari garis-garis yang telah ditentukan oleh bahasanya.

Pada hal ini penggunaan bahasa daerah menjadi acuan dalam pemenuhan kelekatan. Bahasa yang terdiri dari bunyi dan cara berpikir akan menunjukkan bagaimana cara figur lekat merespon sinyal kebutuhan kelekatan pada anak. Ervika (dalam Cenceng, 2015) membuktikan bahwa setiap anak memiliki variasi sinyal kelekatan yang dapat ditangkap oleh figur lekatnya. Penelitian tentang pemenuhan kelekatan dalam konteks bahasa daerah masih belum banyak dilakukan. Namun penelitian tentang dampak tidak terpenuhi kebutuhan kelekatan telah terbukti seperti berpengaruh dalam pembentukan konsep diri (Helmi, 2005), berpengaruh terhadap psikologis sekolah anak (Kennedy \& Kennedy, 2004), hingga berpotensi dalam munculnya simtom gangguan mental (Okello, Mpungu, Musisi, Broekaert \& Derliyn, 2014).

Pada proses pemenuhan kelekatan, anak akan merasa terpenuhi (secure attachment) jika figur lekat mampu menunjukkan sikap dan bahasa yang penuh kasih sayang, positif, dan mendukung. Sebaliknya penyampaian bahasa dengan intonasi keras, kalimat yang negatif, dan megancam akan membuat anak berada pada insecure attachment. Kondisi ini terjadi karena pada tahap perkembangan kognisi anak, khususnya pada masa sensori-motor hingga tahap operasional konkret (usia 05 tahun) anak hanya mampu mengartikan apa yang dilihat dan dirasaknnya. Sehingga sulit bagi anak untuk mengartikan sebaiknya dari ekspresi dan bahasa yang diterimanya. Walaupun orangtua atau figur lekat mengatakan inilah bentuk perhatian dan kasih sayangnya, namun bentakan, kalimat kasar, intonasi keras bagi anak tetap diartikan sebagai ekspresi marah, ancaman, ketidakpedulian dan lain sebagainya.

Bolwby (dalam Bretherton, 1992) mejelaskan lebih lanjut bentuk pola kelekatan aman (secure attachment) ditunjukkan dengan ketika anak berada di 
dekat ibu untuk beberapa saat kemudian melakukan eksplorasi, anak kembali pada ibu ketika ada orang asing, tapi memberikan senyuman apabila ada ibu didekatnya. Anak merasa sangat terganggu ketika ibu pergi dan menunjukkan kebahagiaan ketika ibu kembali. Sebaliknya perilaku insecure attachment ditunjukkan dengan anak menolak kehadiran ibu, menampakkan permusuhan, kurang mampu mengekspresikan emosi negatif. Selain itu anak juga tampak mengacuhkan dan kurang tertarik dengan kehadiran ibu. Berikutnya juga terdapat pola insecure-ambivalent attachment dengan ciri, anak menunjukkan kedekatan dengan ibu sampai tidak mau mengeksplorasi ruang bermain sama sekali. Anak akan marah ketika ibunya meninggalkan ruangan, namun bersikap ambivalen ketika ibu datang kembali. Anak tersebut juga mampu mengekspresikan emosi negatif namun dengan reaksi yang berlebihan.

Penelitian tentang kelekatan (attachment) dalam konteks budaya di Cina menunjukkan bahwa hubungan orangtua baik ayah atau ibu terhadap anak, mulai dari rendahnya kehangatan, penjagaan yang tinggi atau overprotective, serta autoritatif telah terbukti secara signifikan dapat diassosiasikan sebagai penyebab munculnya indikasi gangguan depresi mayor (Gao, dkk., 2012). Sementara hasil penelitian tentang kelekatan dalam konteks budaya di Indonesia masih sangat minim, utamanya dengan masyarakat Bengkulu. Oleh karena itu peneliti ingin melihat lebih jauh pemenuhan kebutuhan akan kelekatan anak dalam konteks budaya Bengkulu.

\section{METODE}

Penelitian ini menggunakan metode kualitatif untuk lebih memahami fenomena apa yang dialami oleh subjek penelitian dalam konteks alamiah dengan memanfaatkan metode alamiah (Sugiono, 2008).

Penelitian ini dilakukan di Kota Bengkulu, tepatnya di Kecamatan Teluk Segara. Kecamatan Teluk Segara berada di tengah Kota Bengkulu, mayoritas penduduk di kecamatan Teluk Segara merupakan penduduk asli Bengkulu yang masih memegang teguh aturan dan nilainilai walaupun terletak di tengah kota Bengkulu.

Responden penelitian adalah figur lekat, dalam hal ini ibu. Subjek diambil secara purposive dengan karakteristik merupakan turunan ketiga yang tinggal dan menetap di Bengkulu, subjek berserta keluarga intinya (suami, istri, anak), tinggal dalam satu rumah (dalam rumah dapat juga dihuni oleh lebih dari satukeluarga), memiliki anak minimal berusia dua tahun, dengan jumlah minimal satu orang, dalam berinteraksi antar anggota keluarga atau antar keluarga menggunakan bahasa daerah yaitu bahasa Bengkulu.

Penelitian ini dilakukan di Kota Bengkulu, Kecamatan Teluk Segara Tengah Padang Bengkulu. Pemilihan seting lokasi tersebut karena berdasarkan sejarah Kota Bengkulu, Tengah Padang merupakan salah satu lokasi yang dijadikan tujuan pendatang dari daerahdaerah di sekitar Bengkulu pada tahun 1840 an. Masyarakat tengah padang sejak awal memiliki kebiasaan, saat anak memulai rumahtangga maka orangtuanya akan membangunkan rumah disekitar rumah tua tersebut (bisa di samping, di depan, atau di belakangnya) sehingga terbentuk keluarga extended yang tidak hanya dekat dari segi silsilah keluarga namun juga dekat secara fisik. Pada penelitian ini ingin melihat penggunaan bahasa daerah oleh figur lekat dalam 
pemenuhan kebutuhan kelekatan anak. Partisipan atau subjek penelitian sebanyak lima orang.

Teknik Pengumpulan data dengan cara wawancara tidak terstruktur dan observasi non-partisipan. Melalui teknik tersebut diharapkan akanmendapat gambaran data interaksi pemenuhan kebutuhan kelekatan antara anak dan figur lekat dengan utuh dan lebih mendalam. Analisis data yang digunakan dalam penelitian ini menggunakan model Spradley (Sugiono, 2008). Model Spradley membagi analisis data dalam penelitian, berdasarkan beberapa tahap, yaitu analisis domain, taksonomi, komponensial, dan analisis tema kultural.

\section{HASIL DAN PEMBAHASAN}

Pemenuhan kelekatan merupakan salah satu kebutuhan psikologis yang telah terbukti akan mempengaruhi cara pandang seseorang terhadap lingkungan sejak sangat awal. Pada usia anak dalam menunjukkan keinginan terpenuhinya kebutuhan kelekatan lebih dominan menggunakan bahasa tubuh dibandingkan dengan bahasa verbal. Hal ini disebabkan karena anak belum mengetahui bahwa kelekatan itu yang mereka cari; maka yang muncul adalah perilaku merengek, menangis, marah, menjerit, dan lain sebagainya. Figur lekat tidak melihat hal itu sebagai kebutuhan psikologis, figur lekat justru melihatnya sebagai perilaku yang mengganggu, yang tidak seharusnya dilakukan meskipun pada level usia balita (1-5 tahun). Interaksi antara ibu dan anak serta anggota keluarga yang lain menggunakan bahasa daerah dalam hal ini bahasa Bengkulu. Bahasa Bengkulu pada dasarnya hampir sama dengan bahasa Indonesia hanya saja rata-rata berakhiran "o". Sama dengan bahasa Indonesia, Bahasa Bengkulu tidak memiliki tingkatan bahasa.
Hasil pengamatan di lapangan menunjukkan bahwa cara figur lekat menyampaikan sebuah pesan menggunakan cara yang sama kepada siapa pun orang yang sedang berinteraksi dengannya. Misalnya saat berbicara dengan orang yang lebih tua sama dengan saat berbicara dengan anak (dari segi pemilihan kata, intonasi, maupun ekspresi non verbal atau bahasa tubuhnya). Jika ditinjau dari pemenuhan kebutuhan kelekatan maka akan muncul sudut pandang yang berbeda antara pemikiran orang dewasa atau dalam hal ini figur lekat dan pemikiran anak. Misalnya teriakan ibu "oooiii...jadilah ambo litak.." (hai...sudahlah saya capek) saat anak merengek meminta perhatian ibu. Pada situasi tersebut orang dewasa bisa memaknai bahwa saat ini saya (ibu) capek sebaiknya nanti saja bermainnya (karena orang dewasa mampu berfikir secara abstrak, dilihat dari tahap perkembangan kognitifnya). Namun oleh anak respon tersebut akan dimaknai sebagai mana apa adanya yaitu ibu capek tidak mau main. Terlebih jika disampaikan dengan ekspresi alis terangkat, mata membelalak, dan nada keras, anak sesuai dengan tahap perkembangan kognitifnya hanya dapat melihat atau menilai sesuatu yang konkret, belum dapat berpikir secara abstrak. Jika hal tersebut dilakukan secara berulang dan tidak konsisten maka akan menyebabkan terbentuknya pola kelekatan insecure attachment sehingga hasil analisis dengan pendekatan kualitatif maka didapatkan hasil bahwa pemenuhan kebutuhan kelekatan dalam konteks budaya Bengkulu termasuk dalam jenis insecure attachment (kelekatan yang tidak aman). Kelekatan ini merupakan kelekatan anak terhadap pengasuh yang kurang mengerti kebutuhan psikologis anak. Anak diasuh oleh orang yang enggan memberikan respon terhadap kebutuhannya, atau memarahi anak saat anak menunjukkan perilaku yang tidak 
menyenangkan. Kebutuhan emosional dalam kelekatan ini tidak terpengaruhi secara hangat seperti secure attachment, akan tetapi figur lekat tetap terlibat dalam tingkah laku lekat. Perilaku yang diterima anak kurang baik, misalnya anak diberikan konsep diri yang buruk, dan tidak efektif dalam pemberian perhatian dan kebijakan. Anak dalam kondisi ini akan sangat beresiko mengalami gangguan perkembangan (Wiebe, 2006).

Bahasa sebagai salah satu produk dari budaya khusunya dalam pemenuhan kelekatan dilihat berdasarkan bagaiman respon figur lekat terhadap perilaku anak. Hasil penelitian ini menunjukkan bahwa bahasa yang digunakan oleh figur lekat merupakan salah satu dari beberapa faktor internal yang mempengaruhi cara figur lekat merespon kebutuhan anak. Hal ini terjadi karena kondisi emosi yang dirasakan figur lekat merupakan akibat persepsi figur lekat terhadap situasi yang dialami dan menjadikan anak sebagai pelampiasannya (Wade \& Tavris, 2002). Tidak hanya persepsi, faktor internal yang lainnya adalah kesiapan mental dalam memasuki pernikahan dan hubungan pernikahan.

Semin (dalam Brewer \& Hewstone, 2004) menjelaskan bahwa proses kognitif dan bahasa sebaiknya dilihat dari sudut pandang secara personal. Proses kognitif dalam berbahasa meliputi berfikir, merepresentasikan, mengambil kembali atau me-recall, menyimpan dalam memori, dan seterusnya juga berlaku dalam konteks sosial. Sehingga menjadikan bahasa daerah yang digunakan oleh figur lekat sebagai alat dalam pembentukan budaya.

Lebih lanjut dijelaskan ketika bahasa digunakan sebagai alat untuk menunjukkan atau memaknai sesuatu, maka hal itu menunjukkan bahwa bahasa, digunakan sebagai media dalam melihat kenyataan dengan cara menyampaikan maknanya. Dalam konteks budaya, Humboldt (dalam Chaer, 2003) menekankan adanya ketergantungan pemikiran manusia pada bahasa. Artinya, pandangan hidup dan budaya suatu masyarakat ditentukan oleh bahasa masyarakat itu sendiri. Menurut Humboldt anggota masyarakat tidak dapat menyimpang dari garis-garis yang telah ditentukan oleh bahasanya. Berdasarkan hasil pengamatan dan wawancara, figur lekat sangat mudah dalam mengeluarkan kata yang mengancam, dan mengintimidasi anak pada level usia berapa pun. Bahasa yang digunakan secara personal akan mempengaruhi orang yang lain hingga membentuk ciri khas masyarakat di suatu tempat.

Pola asuh yang mengabaikan kebutuhan kelekatan tidak hanya dilakukan oleh figur lekat kepada anak saat ini saja, namun juga telah dilakukan oleh generasi generasi sebelumnya, dan besar peluang akan dilanjutkan oleh generasi berikutnya. Terlebih subjek penelitian tinggal berdekatan dengan keluarga besarnya.

Berdasarkan hasil penelitian juga menunjukkan bahwa interaksi antara suami dan istri akan mempengaruhi cara atau gaya figur lekat dalam merespon perilaku lekat anak. Demikian halnya dengan penelitian yang dilakukan oleh Hill, dkk. (2003) membuktikan bahwa suasana atau kondisi lingkungan keluarga akan mempengaruhi pola kelekatan yang akan diterapkan oleh figure lekat dalam keluarga tersebut. Hal ini terjadi karena pada dasarnya elemen kunci dari proses attachment mempengaruhi regulasi, pemahaman interpersonal, pemprosesan terhdap informasi, dan kualitas hubungan intim. 
Meskipun telah digambarkan dan terbukti pengukuran utama kelekatan dilihat berdasarkan fungsi individu dan tahap perkembangannya, oleh karenanya pola kelekatan akan terimplikasi dalam kualitas hubungan keluarga. Sehingga jika dikaitkan dengan kondisi subjek penelitian, maka seolah wajar jika pola insecure attachment yang diterapkan.

Kondisi psikologis yang tidak stabil secara personal akan mempengaruhi gaya komunikasi dengan pasangan (dalam hal ini suami) ditambah munculnya faktor eksternal seperi kondisi ekonomi, tingkat pendidikan, dll. Hubungan interpersonal tersebut akan mempengaruhi gaya kelekatan pada anak. Penelitian ini juga menunjukkan bahwa figur lekat melihat atau memperlakukan anak sebagai objek atas situasi dan kondisi yang sedang dialaminya. Misalnya, saat suami memperlakukan istri (dalam hal ini figur lekat atau ibu si anak) dengan baik, maka figur lekat merespon dengan positif sinyal kelekatan yang saat itu ditunjukkan oleh anak. Seperti memeluk saat anak menangis ketakutan, mendekap erat, dan sejenisnya. Namun yang terjadi sebaliknya saat bertengkar dengan suami maka figur lekat juga akan membentak anak misalnya dengan kalimat "kau ko..samo bae kek bapak kao bigal.." (kamu itu sama saja dengan bapak kamu..tidak tau diri!!) dan sinyal kelekatan yang ditunjukkan anak saat itu tidak direspon oleh figur lekat. Hal ini yang menyebabkan munculnya perilaku yang tidak konsisten kepada anak.

\section{SIMPULAN}

Berdasarkan hasil penelitian dengan pendekatan kualitatif, maka dapat disimpulkan bahwa pemenuhan kebutuhan akan kelekatan pada anak dalam konteks budaya Bengkulu sebagai berikut: 1) Penggunaan bahasa Bengkulu oleh figur lekat dalam merespon kebutuhan kelekatan anak; 2) Figur lekat menerapkan kelekatan tidak aman (insecure attachment); 3) Reaksi spontan berdasar situasi merupakan bentuk respon figur lekat terhadap anak; 4) Intonasi suara dari figur lekat mempengaruhi persepsi anak; 5) Emosi mempengaruhi pemilihan kata pada figur lekat; 6) Faktor internal pemenuhan kelekatan anak, antara lain: kesiapan pernikahan, kualitas hubungan pernikahan, dan kemampuan berbahasa; 7) Faktor eksternal pemenuhan kelekatan adalah kondisi ekonomi, lingkungan dimana subjek tinggal, serta tingkat pendidikan; 8) Anak sebagai objek pelampiasan; 9) Struktur keluarga besar menguatkan kelekatan tidak aman (insecure attachment) pada anak; 10) Pola interaksi dan karakter masyarakat.

\section{DAFTAR PUSTAKA}

Bretherton. (1992). The origin attachment theory: John Bowlby and Mary Ainsworth. Developing Psychology, 28(5), 759-775.

Brewer, M. B., \& Hewstone, M. 2004. Social cognition. Hoboken: WileyBlackwell.

Cenceng. (2015). Perilaku Kelekatan pada Anak Usia Dini (Perspektif Jhon Bowlby). Lentera, 19(2), 141-153.

Chaer, A. (2003). Psikolinguistik kajian teoretik. Jakarta: Rineka Cipta.

Helmi, A. F. (2005). Studi Meta-Analisis Gaya Kelekatan dan Model Mental Diri. Tugas Metode Penelitian Kuantitatif: Meta Analisis (tidak dipublikasikan). Program Pra S3 Fakultas Psikologi UGM. 
Hill, J., Fonagy, P., Safier, E., \& Sargent, J. (2003). The ecology of attachment in the family. Family Process, 42(2), 205-221.

Gao, J., Li, Y., Cai, Y., Chen, Shen, Y., Ni, S., Wei, Y., Qiu, Y., ..., Tao, M. (2012). Perceived parenting and risk for major depression in Chinese women. Psychological Medicine, 42(5), 921-930.

Kennedy, J. H. \& Kennedy, C. H. (2004). Attachment theory: Implications for school psychology. Psychology in the Schools, 41(2), 247-259.

Okello, J., Nakimuli-Mpungu, E., Musisi, S., Broekaert, E., \& Derluyn, I. (2014). The association between attachment and mental health symptoms among school-going adolescents in Northern Uganda: The moderating role of war-related trauma. Plos One, 9(3), 1-7.
Santrock, J. W. (1999). Life-span development, seventh edition. Boston: McGraw-Hill.

Sugiono. (2008). Metode penelitian pendidikan pendekatan kuantitatif, kualitatif, dan $R \& D$. Bandung: Alfabeta.

Wade, C. \& Tavris, C. (2002). Psikologi. Edisi ke-9 jilid 2. Jakarta: Erlangga.

Wiebe, V. J. (2006). Parent-child and attachment defence mechanism: A development perspective on risk taking behavior in clinical sample adolescents (Disertasi). Canada, Simon Fraser Universitty. 